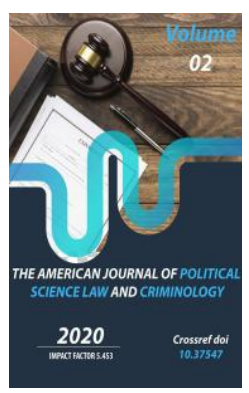

\title{
The Protection Of Consumer Rights In Retail Trade In Accordance With The Laws Of The Republic Of Uzbekistan
}

\author{
Djakhongir Ismailbekovich Babaev \\ Candidate In Law (PhD), Professor At The Department “Civil Law" Of Tashkent State University \\ In Law, Republic Of Uzbekistan
}

Copyright: Original

content from this work may be used under the terms of the creative commons attributes 4.0 licence.

\section{ABSTRACT}

The needs of the population in consumer goods are met through retail activities. Individuals who buy goods at retail are consumers, and the protection of their status and rights in this legal relationship is constantly relevant. The increase in the volume of retail trade in recent years, as well as the fact that retail trade is carried out in conjunction with the types of trade services, also creates new challenges and risks to consumer rights. This highlights the need to introduce effective and comprehensive methods of consumer protection, to identify measures to prevent violations of consumer rights and to develop mechanisms for the restoration of violated rights, which are fast and easy to implement. Factors such as providing complete and reliable consumer information on retail trade, monitoring the quality and range of goods at the level of established requirements, enhancing the business reputation and goodwill of retail entities.

\section{KEYWORDS}

Consumer, brand, retail, rights protection, seller, buyer, restoration of violated rights, damage, liability.

\section{INTRODUCTION}

The protection of the rights and interests of consumers in the process of production and provision of services is of paramount importance. Because when a consumer buys a product, he is unaware of what quality it is and under what conditions it was stored before the 
product was purchased. Only the seller of this type of product knows about it. In this sense, the consumer is deceived in such cases, which leads to a violation of his rights as a consumer. It should be noted that Uzbekistan has a legal framework for consumer protection. On April 26, 1996, the Law “On Consumer Protection" was adopted, which provides for direct and complete information about the goods (works, services) of the consumer, as well as the manufacturer, executor, seller, goods (works, services). free choice and its adequate quality, safety of goods (works, services), goods (works, services) with dangerous defects for life, health and property, as well as illegal actions (inaction) of the manufacturer, executor, seller The process is aimed at protecting the rights and interests of consumers, such as appealing to the court and other competent state bodies for protection of their violated rights or legally protected interests, the establishment of public associations is being implemented. Consumer protection is one of the most pressing issues in the context of market relations. Despite the creation of a legal framework that guarantees the rights and interests of consumers, there are still cases of selling low-quality goods, providing substandard services. One of the reasons for this is that consumers are not sufficiently aware of their rights. The retail sector plays an important role in providing the population with the necessary goods. Citizens who purchase goods from retail will have consumer status. As consumers, citizens have a number of rights in the retail sector. This is due to the rule that "the consumer is always right". This is because the necessary goods are also produced for the consumption of the population. In any case, the consumer market, as long as there is no consumer, there will be no production and sale of goods. Therefore, there is a need to protect the rights of consumers in the retail sector. After all, experts say that the "weak" side of retail relations is the consumer. In the process of purchasing or ordering a product, the consumer may not know the scope and extent of his rights and have no idea how to exercise them. Therefore, there are many cases of violation of his rights. Also, the protection of consumer rights is an important issue for the state and society. Article 53 of the Constitution of the Republic of Uzbekistan stipulates that the state guarantees freedom of economic activity, entrepreneurship and labor, equality of all forms of property and equal legal protection, taking into account the supremacy of consumer rights. Uzbekistan has a legal framework for consumer protection and has institutional structures (various governmental and non-governmental organizations). In particular, the Law of the Republic of Uzbekistan "On Consumer Protection", "On Food Quality and Safety" and the "Rules of retail trade in the Republic of Uzbekistan" approved by the Cabinet of Ministers of February 13, $2003 \quad № 75$ directly affect consumers in the retail sector rules for the protection of their rights. Federations of consumer protection societies of Uzbekistan directly contribute to the protection of consumer rights.

The UN General Assembly Resolution 39/248 of 9 April 1985 on Guidelines for the Protection of Consumers' Interests is an international legal instrument on consumer protection, which lists 8 basic rights of consumers. Foreign countries also have a special system of legislation aimed at protecting the rights of consumers, and there are government agencies. 


\section{METHODS}

Methods such as logical analysis, systematic, problem-oriented, interpretation of legislation and scientific articles, comparative-legal analysis were chosen to write a dissertation on consumer protection in the field of retail trade. Although there are a number of laws regulating the protection of consumer rights in the retail sector today, it is impossible to say that they have a certain consistency and are effectively used in the protection of consumer rights. For example, there are not enough concrete measures to ensure consumer rights and the means to prove the claims in their protection. Also, the establishment of limited liability to the manufacturer, seller, service provider and contractor in the protection of consumer rights does not allow the full implementation of consumer rights.

\section{RESULTS AND DISCUSSIONS}

It has become common for consumers to be distracted by the sale of counterfeit products, and for sellers to sell low-quality products at high prices, using terms such as "original" and "not original", which are widely used by sellers. However, the legislation does not have an effective system and measures in place to prevent this negative reality. In recent years, the development of science and technology has led to an increase in the number of goods with a complex technical structure in trade, which in many cases not even aware of the system and characteristics of such goods. The consumer, on the other hand, knows that such goods use only certain functions. Instructions for the use of these goods are often not available, and some are not in the state language. As a result, it leads to violations of consumer rights. In retail relations, legal scholars have always recognized the buyer- consumer as a "weak point". Most of the legislation is also adopted mainly in terms of protecting the rights and interests of the buyer-consumer. Although the consumer is a "weak point" in retail relations, they should not allow this situation to be abused for their own benefit. However, in recent years, in practice, especially in developed countries, this criterion is often abused by consumers. For this reason, the concepts of "aggressive consumer" and "unscrupulous consumer" should be considered. Some of the published articles on consumer protection in the retail sector have been highlighted. In particular, the article by V.A. Pavlova "Civil-legal means of protection of the rights and interests of consumers" [5] analyzes the means of protection of consumer rights in pre-trial and judicial proceedings. The author makes suggestions for improving the system of consumer protection using the method of comparative legal analysis. The article analyzes U.S. consumer protection legislation. According to it, consumer protection relations have more than fifty pieces of legislation, including the Law on Consumer Protection, the Law "On Guarantees for the Sale of Consumer Goods", the Law on the Federal Trade Commission, the simplification of food safety measures. Food Safety Modernization Act, separate state laws, as well as laws in various fields of activity, the Truth in Lending Act, and others. Pre-trial protection of consumer rights means the protection of rights by public organizations and government agencies, as well as the self-defense of citizens (claim process).

E.A. Talabaev's article "Problems of consumer protection in the sale of goods" [7] addresses issues of consumer protection in the purchase and sale of goods. The author points out the 
cases of violation of consumer rights in the field of trade (lack of precedents about the seller, insufficient information about the product, its quality and characteristics) and argues that in these cases the legislation should provide adequate mechanisms to protect consumer rights. At the same time, the issue of compensation for moral damage is also important. If the consumer is aware of their rights and knows how to protect them, the issue of interest will have to be resolved. Typically, the damage suffered by the consumer is small, and claiming the right to recover it leads to undesirable costs, which means that consumers do not try to protect their rights, and this is exploited by unscrupulous sellers and manufacturers. In 2004, an amendment to the Law of the Russian Federation "On Consumer Protection" to impose a fine of $50 \%$ of the claim on the plaintiff in favor of the seller or manufacturer slightly adjusted the situation. However, in the case where goods are often purchased, when the amount is small, the consumer has only one option left, which is the right to claim compensation for non-pecuniary damage. In Dmitry Medvedev's article "Protection of the rights of consumers in contractual relations" [4], the relationship of consumer protection in many cases arises from the contractual relationship and has the nature of protection. One side of the contract is the mechanism of protection against dishonest behavior regulated at the legislative level. In doing so, the consumer protects his rights by appealing to the administrative bodies of the state, the courts and public organizations. Even because the relationship in the consumer participant arises from collective agreements, the legislature imposes enhanced liability measures on only one party (manufacturer, contractor, service provider). At the same time, the issues of consumer protection in Uzbekistan were studied at the level of PhD dissertation by N.Said-Gazieva, D.I.Bababev, H.Burkhankhodjaeva. In particular, N.SaidGazieva in the field of consumer protection [6], D.I.Babayev in the field of consumer services and the problems of civil liability for their violation [1] H.V.Burkhankhodjaeva in the field of trade services consumer rights [2] were analyzed. The retail sector is one of the activities that directly affects of consumers. Because the ultimate goal of production is focused on retail, and through this stage the goods are delivered to the consumer. Therefore, special attention is paid to the legal regulation of this area and the protection of consumer rights. The concept of retail is usually understood as the sale of goods to citizens in pieces or in small quantities. The legal definition of this concept is the Cabinet of Ministers of the Republic of Uzbekistan. The Rules of Retail Trade in the Republic of Uzbekistan, approved by the Resolution №75 of February 13, 2003. According to him, retail trade is the implementation of activities in the field of trade for the final consumer, which involves the sale of goods in cash or in small quantities to the population without the right to use them for commercial purposes.

The UN General Assembly's Guidelines for the Protection of Consumers' Interests (Resolution №39/248 of April 9, 1985) on the right to a product of the required quality, which is one of the basic rights of the consumer, states in the legislation of the European Economic Community This is reflected in the Law "On Consumer Protection" (Article 4 of the Law). This right allows the consumer to express certain requirements for the quality and safety of any product. In other words, it means that 
the consumer has the right to get acquainted with the information on the quality of the goods, to check that the goods are safe, and that this requirement must be met by the manufacturer or seller. Therefore, manufacturers will have to follow certain rules, requirements and conditions that determine the quality of the goods. In practice, there are indicators and criteria for identification and designation as a commodity the fact that a product is developed in accordance with such criteria, indicators and requirements determines its level of quality [3]. As a rule, the quality information of the goods is represented in the quality certificate of each product. The quality certificate represents the structural structure of the goods and allows determine whether it meets the requirements for this type of goods. The quality certificate contains other information about the product: the manufacturer of the product, the address of application, if necessary, whether the product has passed the requirements of standardization, in some cases, some instructions for its use. The quality certificate of some types of goods may also contain information about the shelf life (shelf life) of the goods. The current Civil Code sets out a number of rules regarding the quality of goods. In particular, Part 1 of Article 402 of the Civil Code, entitled "Quality of goods", states that "the seller must deliver to the buyer goods whose quality corresponds to the contract of sale." In other words, the goods delivered to the buyer-buyer and at the same time to the consumer must correspond to the quality of the goods provided for in the contract of sale concluded between the parties. This in itself shows that the quality of the goods can also be understood from the terms of the contract. In any case, the goods delivered by the seller to the consumer must be of good quality and its quality must be understood by mutual agreement of the parties. If the agreement between the seller and the consumer is to sell a product of low quality, with certain shortcomings and defects at a low price, and then the consumer demands the delivery of goods of the required quality, then the consumer is unfair. Because, in this case, the seller delivers to the consumer the goods, the quality, which corresponds to the contract of sale, in accordance with the provisions of Part 1 of Article 402 of the Civil Code, and sets the price for him in this case. As a rule, if the contract of sale does not specify the conditions of quality of the goods, the seller must deliver to the buyer the goods that are suitable for the intended purpose (Article 402, Part 2 of the Civil Code). According to experts, if the buyer's contract stipulates a special quality of the goods, then the quality of the goods should be suitable for the same purposes for which these types of goods are usually intended for use. In this case, it is sufficient that the product has a general quality that can be used for its intended purpose [8]. If the seller does not have the goods required for replacement, the buyer has the right to return the purchased goods to the seller and get a refund of the amount paid for it. The buyer's demand for replacement or return of the goods must be satisfied, if the goods are not consumed, its appearance, consumer properties, fillings, labels are preserved, as well as proof of purchase from this seller, in the list of non-food items of the required quality with the exception of goods specified in such a size, shape, dimension, shape, color or which cannot be exchanged for another commodity in the set. The buyer who sold the goods that do not have the required quality, from the 
seller of his choice, if the defects are not mentioned by the seller (in respect of food products, the buyer has such a right within 24 hours after purchase): replacement of goods of the same brand (model, article); replacement of the same product of another brand (model, article) with the corresponding recalculation of the purchase price; proportional reduction of the purchase price; defects of the goods are immediately eliminated free of charge; have the right to claim reimbursement of defects in the goods. In this case, the buyer has the right to demand full compensation for damage caused to him as a result of the sale of goods of substandard quality.

In case of serious violation of the quality requirements of technically complex or valuable goods (detection of irreparable defects, irreparable defects without proportionate costs or time, if defects are repeatedly detected or reappeared after elimination, and other similar defects), the buyer can replace it has the right to demand. In the event that the buyer requests the seller to remedy the defects of the durable goods or the replacement of such goods, the buyer shall have the right to demand the delivery of the same quality goods at the same time during the repair period or during the replacement of the goods. They are excluded from the list of durable goods, in respect of which the buyer's demand for the free transfer of such goods to him during the period of repair or replacement does not apply. In case of detection of defects of the goods, the properties of which can not be eliminated (cosmetics, household chemicals and other goods), the buyer has the right to demand the replacement of such goods with goods of the required quality or a corresponding reduction in purchase price.
Instead of submitting the specified claims, the buyer has the right to reject the purchased goods and demand a refund of the amount paid for the goods. When replacing or returning goods that do not have the required quality, the buyer must return the goods that he did not have the required quality at the expense of the seller. When returning the amount paid for the goods to the buyer, the seller has no right to deduct from the buyer the amount of value of the goods due to full or partial use of the goods, loss of its appearance or other similar circumstances. The selleremployee or the person performing the functions of the seller on the basis of the contract, if it is necessary to check the quality of the goods, is obliged to accept from the buyer the goods that do not have the required quality. The buyer has the right to participate in the inspection of the quality of the goods. In the event of a dispute over the causes of defects in the goods, the seller must conduct an independent examination of the goods at his own expense.

The buyer has the right to appeal in court against the conclusion of such examination. Terms of satisfaction of the buyer's requirements by the seller, and also the responsibility for infringement of these terms are established according to the Law of the Republic of Uzbekistan "About protection of the rights of consumers". Part 2 of Article 402 of the Civil Code stipulates that if the quality of the goods is not specified in the contract, the buyer must deliver the goods for the intended purpose the goods are suitable for their intended use. This criterion applies only if the contract does not contain a condition on the quality of the goods. In our view, it should be applied independently, whether or not there is a quality clause in the contract. This rule is 
expedient, because no contract, no standard does not fully explain the conditions of quality of all goods (works, services), including the simplest, so-called. This is because in the event of a dispute between the parties over the quality of goods (works, services), they must be taken into account. In this case, the question of the suitability of the goods and the discrepancy between the conditions quality is determined. Indeed, as is highly acknowledged, the seller and the consumer can agree to sell goods that are of poor quality and in some cases even unusable, in which case the rule that the seller must deliver the goods to the consumer in all cases would be a legal error. For this reason, the current legislation stipulates, first of all, that the goods correspond to the quality stipulated in the contract and are suitable for the purposes specified in the contract, if the quality condition is not included. In other words, if the seller and the consumer have not reached an agreement in the contract on the quality of the goods, then the seller must deliver a suitable product to the buyer, otherwise he will compensate the damage caused to the consumer.

\section{CONCLUSION}

The types and areas of retail are wide and varied. Therefore, the legislature has established special rules, procedures and instructions for the sale of certain types of goods. However, there are no rules and requirements for trading in complex electronic products (phones, computers, tablets, smart watches, etc.), which today have become widespread consumer goods. This creates various problems and can lead to violations of consumer rights. In order to prevent these problems, it is necessary to adopt requirements for the sale of electronic consumer goods in the Republic of Uzbekistan and to establish the requirements for sellers to have the appropriate knowledge and skills for the sale of such goods. The definition of the purpose of delivery of goods in retail trade is explained by the fact that it implies the restriction of dishonest consumer behavior and the protection of the interests of the manufacturer (sometimes the state). In this case, firstly, the goods delivered to the buyer under a retail contract are recognized as consumer goods, and secondly, the purpose of Article 425 of the Civil Code, the regulation of relations between the buyer and the seller to protect their interests. Due to the fact that the retail contract must treat both parties equally, in our opinion, the normative legal acts should stipulate that the party claiming that the goods are defective, invalid, should examine it and charge the costs of examination only if the claim is proved. The "aggressive consumer" is more likely to take advantage of such situations. They can act in different ways. Article 426 of the Civil Code should be called "a form of retail contract" (Article 426 will be a separate article, respectively) and should be worded as follows: Unless otherwise provided by law or the contract of retail sale, the contract of retail sale shall be deemed to have been concluded by the seller in the prescribed form after the receipt of a receipt or a receipt or other document confirming payment of the goods to the buyer. The absence of the documents specified in the buyer does not deprive him of the opportunity to use the testimony of witnesses to confirm the conclusion of the contract and its terms. Unless otherwise provided by law or the contract, the contract of retail sale shall be deemed concluded after the buyer has paid the seller 
for the goods. The buyer has the right to return the goods and receive payment for it within ten days, without specifying the reasons. The procedure and conditions for returning the goods to the buyer shall be established by the legislation. As a general rule, one of the requirements for a seller in a retail contract is that he be kind to customers. Being rude, on the other hand, can upset the buyer and cause him or her moral damage. This is always considered a violation of the law. It is therefore advisable to establish strict liability measures in civil law for the buyer's rude behavior. In our opinion, it would be expedient to include the following norm in the "Retail Rules": - in case of rude treatment of the buyer by the seller, the measure of responsibility established by the legislation is applied. In this case, the buyer must compensate the moral damage caused to the seller. The seller shall be held liable in accordance with the Code of the Republic of Uzbekistan on Administrative Liability for illtreatment of the buyer. The second part of Article 5 of the Law "On Consumer Protection" should be worded as follows: The seller (executor) must inform the consumer of the firm name of his organization, its location (legal) address and the order of business. Such information should be reflected on the plate, its text and font size should be easy to read and understand for the consumer.

\section{REFERENCES}

1. Babaev D.I. Problems of consumer rights and civil liability for their violation: Dissertation for the degree of candidate of legal sciences.-Tashkent, 2005. - 170 p.

2. Burkhanxodjaeva Kh.V. Civil law issues of trade services to the population:
Dissertation for the degree of candidate of legal sciences.-Tashkent, 2007. - 176 p.

3. Dmitriev M.A. On the question of how to protect the rights of a buyer under a retail sale agreement // Lawyer. - 2013. -№ 9.

4. Medvedeva D.I. Protection of consumer rights in contractual relations // Law and order: history, theory, practice. 2015. -№.2 (5). - p. 26-28.

5. Pavlova V.A. Civil law means of protecting the rights and interests of consumers // Territory of Science. 2014. - №. 6. - p. 107112.

6. Said-Gazieva N.Sh. Consumer protection in the field of public services. - Tashkent: TSIL, 2005. - 136 p.

7. Talabaev E.A. Problems of consumer protection when selling goods // Electronic scientific journal "Science. Society. State" 2018. Vol. 6, №.1 (21) http://esj.pnzgu.ru ISSN 2307-9525 (Online).

8. Commentary to the Civil Code of the Republic of Uzbekistan.Volume 2. Tashkent: Baktria press, 2013. - 31 p. 